\title{
Theodore Dreiser's Philosophy and Its Effect on Hurstwood's Downfall in Sister Carrie
}

\author{
Saihanqiqige ${ }^{1, a,{ }^{*}}$ \\ ${ }^{1}$ Editorial Department, Journal of Chifeng University, Chifeng University, Chifeng, \\ China \\ a1399789355@qq.com \\ ${ }^{*}$ Corresponding author
}

Keywords: Naturalism, Theodore Dreiser, Sister Carrie.

\begin{abstract}
Theodore Dreiser is famous for his work's truth and dependability, and in the novel- Sister Carrie, Dreiser draws a vivid picture of American life in the late $19^{\text {th }}$ century, the vividness depends on his own experience and the influence of the Naturalism, and which help form his own philosophies on life. This paper will show Dreiser's own Naturalism by giving a detailed analysis of Hurstwood's fall. In Dreiser's eyes, the desire for Carrie is not the unique reason for Hurstwood's decline. Dreiser believes that man cannot control his own life and man is just a victim of society. In the world that society force control everything, man cannot escape from himself, from his personality. Once Hurstwood leaves Chicago for New York, his tragic ending is destined. When we explore the cause of Hurstwood's fall, we also know Dreiser's philosophy that man's fate is unpredictable in the capitalist society and the certain circumstances and social system control a man's fate, nobody can predict what the future will bring to him.
\end{abstract}

\section{Introduction}

Theodore Dreiser was one of America's greatest writers, and greatest naturalist writers. He and his characters did not attack the nation's puritanical moral code: they simply ignored it. This attitude shocked the reading public when his first novel, Sister Carrie, came out in 1900. Although we see it as a masterpiece, it was suppressed until 1912. The heroine, Carrie Meeber, leaves the poverty of her country home and moves to Chicago. She is completely honest about her desire for a better life: clothes, money and social position. She is quite modern in the way. She moves from one relationship to another for pursuing her desire. She tries to be faithful to them, but circumstances make this impossible. Almost, by accident, she becomes a success as an actress. In the end, however, she learns that even money and success are not the keys to true happiness.

As in all of his novels, Dreiser's real theme in Sister Carrie is the purposelessness of life. While looking at individuals with warm, human sympathy, he also sees the disorder and cruelty of life in general. While one character, Carrie gains fame and comfort, another character. in the novel, Hurstwood, loses his wealth, social position and pride. This character's tragedy is just as accidental as Carrie's success. Dreiser does not try to explain why these things happen. In his form of naturalism, the working of fate can never be explained. Dreiser has his own philosophies toward life, and which will be seen in the process of depicting the decline of Hurswood. The essay tries to show the Dreiser's philosophies through the detailed analysis about Hurstwood's decline. 


\section{Theodore Dreiser and Sister Carrie}

\section{Dreiser's Own Experience and the Influence of Naturalism}

Theodore Dreiser was one of the American's greatest writers and pioneer of naturalism in American writing. He wrote many works in his life, his masterpiece was Sister Carrie.

Theodore Dreiser was born in a large and catholic, immigrant and impoverished family in Terre Haute, Indiana, on August 27, 1871. In his childhood, Dreiser experienced grim poverty, his father's stern catholism, and the chronic misadventures of his brothers and sisters. All his life, he explored the truth of life and wanted to understand its mysteries. In the 1890's, Dreiser began to to read the philosophy of nineteenth century's mechanism: Darwin, Spencer, Tyndall and Huxley, anything to do with religion, he found on mechanism a scientific sanction for suffering, he defied conventional morality and thus allied himself with naturalists, who were attacking the canons of a more genteel tradition and addressing themselves to new social problems. His naturalism was just arrived from that mechanistic concept of life that says man as the victim of instincts, social forces, economics, and chance.

\section{About Sister Carrie}

In the autumn of 1900, Dreiser began to write Sister Carrie- his first novel. But its first publication ended with defeat. Because at that time, lust and vice should be punished in the end; instead, unchaste Carrie, far from being punished, became a successful actress gained everything splendid: wealth, money, reputation and so on. Judged by the stiff moral and aesthetic standards of 1900, Sister Carrie was labeled immoral and vulgar. The novel was too far ahead of its time. As time passed, people gradually changed their views; the novel had been called one of the best powerful naturalistic novels by some famous novelists and critics. The truth and depth of the novel moved almost every reader. In the novel, Dreiser presented most of his philosophical ideas. Through this novel and some of his other works, Dreiser sought to free the novel both from Victorian notions of decorum and from the realistic literary theory that the novelists' task is simple to reproduce ordinary life. Dreiser is regarded as a pioneer of naturalism in American literary. Very surely, Sister Carrie contributes to fixing Dreiser's reputation as a famous novelist.

\section{Dreiser's Philosophy's Effect on Hurstwood's Decline}

Many good examples in the novel present obvious and vivid evidence of Dreiser's philosophy. Among them, Carrie's rise and Hurstwood's decline, Hurstwood's decline perhaps presents the best example. For without Hurstwood's decline as the counterpart of Carrie's rise, Sister Carrie is not complete. Some critics feel that the novel's plot and they are strong enough to overshadow the shortcoming in Dreiser's style and language. It is difficult to find another novel whose characters' experiences are more changeable and frustrating than those in Sister Carrie. We can say, Hurstwood's decline is the deepest presentation of Dreiser's philosophy in the novel. In Dreiser's eyes, "Man's life is insignificant and determined by inner and outer force beyond his control. These forces are very powerful, and include instinct, inheritance and environment-especially the effect from the social environment, but also the effect from some occasional elements. These are the developed Main ideas of Mechanism."'[1] As we read in Sister Carrie, it is the force (outer and inner) that decides Hurstwood's decline.

When Hurstwood first appeared before us, he was the manager of Fitzgerald and 
Moy's -"really a gorgeous saloon from a Chicago standpoint."[2] "He had been pointed out as a successful and well - known man about town." [3] But when the novel draws to a close, "...Hurstwood stood before a dirty four story building.."[4]After he "laid down his fifteen cents..."[5] "the money which he had begged from the pedestrians in the cold" he just went to sleep in one of the rooms that were "dingy affairs"[6]very obviously, at that time, Hurstwood's decline is complete. Then, immediately following that the next step he planned to do and he did was just "turned the gas (the coal gas in the lamp) on..." [7], but "applied no match."[8] later, we know, "a slow, back bout setting out from the pier an twenty-seven street upon its weekly arrant bore with many others, his (Hurstwood's) nameless body to the potter's field(a grave).'[9] Very euphemistically, Hurstwood ended his life with the coal gas. Here, Dreiser tells us his belief in the cyclical nature of human life, the movement from youth and health to old age and sickness -and eventually death. The spirit of both aspiration and desperation are built into the human condition, no one embodied this dual spirit more truly than Hurstwood.

In spite of his naturalistic philosophy, Dreiser did not copy Mechanism. It was rather more complicated than Dreiser perceived it. Dreiser altered mechanism into his own notions of "Chemism", [10] which was influenced by Freudianism. In his mind," a chemic compulsion of those desires and drives which are usually unconscious." [11] in terms of his naturalism, desire is just need, or animal's instincts in man and man's mind or sense cannot go beyond the control of man's instincts. Like many other naturalists, Dreiser also regarded desire as a land of dominant force. It often has effects on people together with other forces. The motivation of all people's behavior is basically caused by the need to satisfy their own desires. From these ideas, we know why Hurstwood wanted to steal money -that directly, caused Hurstwood's downfall, meanwhile, his wife's punishment quickened and deepened his downfall.

Before he saw Carrie, Hurstwood deeply understood: "he could not complicate his home life, because it might affect his relations with his employers. They wanted no scandals. A man, hold his position, must have a dignified manner, a clean record, a respectable home anchorage"[12] therefore he was "circumspect in all he did, and whenever he appeared in the public ways in the afternoon, or on Sunday, it was with his wife, and sometimes his children. He would visit the local resorts, those nearly in Wiscosin, and spend a few stiff, polished days strolling about conventional places doing conventional things. He knew the need of it" [13] these clearly show that Hurstwood had strong reason. Though he disliked the stiff things. He still conformed to his reason.

Very soon, Carrie appeared. She "came fresh from the air of the village, the light of the country still in her eyes."[14]"in the mild light of Carrie's eyes was nothing of the calculation of the mistress. In the different manner was nothing of the art of the courtesan.”[15]

To Hurstwood, Carrie "represented a better order of woman..."[16] So his desire was vigorously aroused. What's more,"the reason for his interest, not to say fascination, was deeper than mere desire. It was a flowering out of feelings which had been withering in dry and almost barren soil for many years."[17] The feeling was strong that in the face of "his lovely prize(Carrie), so beautiful, so winsome, and so difficult to be won..."[18] Hurstwood "had gotten to that stage now"[19] He would make a try for paradise, whatever might be the result. He would be happy, but the lord, if it cost all honesty of paradise, whatever might be the result. He would be happy, by the lord, if it cost all honesty of statement, all abandonment of truth."[20] At last, his strong reason conformed to his desire or instinct. Man is the victim of the instincts, 
social force, economics, and chance.

From then on, Hurstwood lost control allowing his instinct to guide him. He did not attend to his responsibility at home or in the public any longer. He begun to walk or ride with Carrie, or to invite Carrie and Drouet to some splendid theaters regularly: he tried his best to avoid his wife's requests to fulfill their matrimonial tasks. Mrs.Hurstwood could not forgive her husband's disloyalty. In her mind, her position in her family could not be changed. Even if love between them disappeared, the task had to be continued. So she would punish her husband. Hurstwood was defeated by his wife's hate. The relationship between him and family collapsed, all his property was owned by his wife (because all his property was put under his wife's name for fear of danger.) Hurstwood had nothing, which caused his motivation to steal the money.

Dreiser chose Spencer as his Cyrus of philosophy, but meanwhile, he was also strongly attracted by mysticism in Sister Carrie, Dreiser obviously emphasized a kind of mysterious force, it can also be called luck or chance. It is also a kind of dominant force, and belongs to a part of the universal force network. It was the force that realized Hurdtwood's motivation to steal the money.

Dreiser, who felt that most lives were determined by accident rather than intention, makes one significant change in his story. Hurstwood does not plan, or really want, to steal the money he takes with him. One evening, he is so upset by a quarrel with wife, who has learned something of his interest in Carrie, that he drinks a little more than usual. He is rather confused when he goes into his office to put the night's receipts into the safe which the day manager has, as usual; left open for him, there is an unusual amount of cash there and he takes it out, thinking how easy that would make the elopement. As he begins putting it back, he accidentally pushes the door of the safe, which locks itself, in his confusion, it seems to him impossible how to explain why he had taken the money out of the safe at all. Almost accidentally he steals it. In fact, no one knows what on earth shut the safe. We only know it was just one chance event that ended Hurstwood's hesitation and changed his wavering into realization. As a man, Hurstwood was "poor, blind fool."'[21] He had no mind to control or direct his behavior; the universal force he couldn't understand by himself only controlled his behavior. Here, we know that, man can do nothing but conform to the force.

In Dreiser's mind, the universal force is powerful and under its control, the nature of life is full of wonders and fear, the world also becomes the place where the conflicts among many blind forces. Man lives in those forces only like a tramp. In other words, those forces are the owners of the world; while man is only the slave, so in the face of the blind forces, all efforts (including struggle and hard, long-lasting consideration) people make are vain and transitory.

\section{Conclusion}

In American literature, Theodore Dreiser is famous for his work's truth and dependability. He always presented life as he saw it, raw and ungrammatical, unpolished and tragic. Most of his works are modeled on true things in his life including the experiences of his own, his sisters and brothers. Sisiter Carrie also belongs to one of them. The novel's main plot is true; the main characters also come from true prototypes. For example, Hurstwood's prototype is one of Dreiser's sisters. So Dreiser was even called the elder brother of Sister Carrie by some people with ill-will. We can say Sister Carrie's vividness mostly depends on the real thing. To the vividness, the author added his philosophy in which man is a mere machine run by 
forces that he cannot understand, he was deeply moved by the revelations of the forces. Then his philosophy also became vivid. At the same time, Dreiser responds to his fellow man in a very immediate and sympathetic manner, but more importantly, despite the limits of his vision, he understands human beings. His understanding goes far beyond the determinism and chemisms through which he seeks to explain them. Were Dreiser enable to understand humanity in terms other than his restrictive philosophy, readers would not discover in his novels insights about other human beings which they did not have before. In short, Theodore Dreiser is a better artist than his philosophy would allow him to be. So, Dreiser can unite the characters in the novel with his philosophy very excellently. When we explore the cause of Hurstood's downfall, we also know Dreiser's philosophy and ideas.

\section{References}

[1] Balling, Frederick J, Cliff Notes on Dreiser's Sister Carrie. Lincoln, Nebraska: Cliffs Notes, Inc. 1967.p.89.

[2][3]Dreiser, Theodore. Sister Carrie, China: Foreign Language and Research Press.1992.P.43

[4] Ibid, 378.

[5][6][7][8] Ibid, 380 .

[9] Ibid, 380.

[10][11] Balling, Frederick J, Cliff Notes on Dreiser's Sister Carrie. Lincoln, Nebraska: Cliffs Notes, Inc. 1967.P.90.

[12][13] Ibid, 76.

[14][15] Ibid, 102.

[16][17] Ibid, 101.

[18][19][20] Ibid, 66.

[21] Ibid, 205. 